\title{
Molecular Investigation for Matrix Gene of Newcastle Disease Virus in Non-vaccinated Village Chickens in Central Rift Valley of Oromia, Ethiopia
}

Ashenafi Milkesa ( $\sim$ moataj1milk@gmail.com )

Adama Science and Technology University, School of Applied Natural Science, Department of Applied Biology

Hunduma Dinka ( $\nabla$ dinkahu@gmail.com )

Adama Science and Technology University https://orcid.org/0000-0002-3498-7689

\section{Redeat Belaineh}

National Animal Health Diagnostic and Investigation Center

Abde Aliy

National Animal Health Diagnostic and Investigation Center

Research

Keywords: Central rift valley, M-gene, Newcastle disease, RNA, qRT-PCR, Village chicken

Posted Date: March 30th, 2020

DOl: https://doi.org/10.21203/rs.3.rs-18290/v1

License: (9) This work is licensed under a Creative Commons Attribution 4.0 International License.

Read Full License 


\section{Abstract}

Background Newcastle disease (ND) is a major infectious disease of poultry caused by a virulent strain of Avian Paramyxovirus - 1. It is a major threat to the poultry industry in many countries of the world including Ethiopia. Newcastle Disease Virus (NDV) is an enveloped, non-segmented, single-stranded negative-sense RNA virus with a helical morphology whose genome has six open reading frames (ORF) which encode for the following proteins: nucleoprotein (NP), phosphoprotein (P), matrix protein (M), fusion protein $(F)$, hemagglutinin-neuraminidase $(H N)$ and RNA-dependent RNA polymerase $(L)$. The aim of this study was to detect matrix gene (M-gene), for NDV by molecular tools and identify its risk factors in non-vaccinated village chicken in Central Rift Valley of Oromia, Ethiopia.

Methods A total of 84 pooled in five swab samples from 420 cloacal and tracheal chickens were sampled and RNA was extracted from the 84 pooled samples to carry out real-time quantitative polymerase chain reaction (qRT-PCR). A real-time reverse transcriptase polymerase chain reaction ( $r R T-P C R)$ along with the quantification was also done for 10 positive qRT-PCR samples that were having high concentration of viral load Ct. value.

Results Out of the 84 pools of five swab samples tested for M-gene using qRT-PCR, 16.7\% (14/84) samples were detected which included 13 positives and 1 negative for NDV. The prevalence of ND in males was found to be $16.10 \%$ and that in females was $14.67 \%$. Although the overall ND prevalence was $15.48 \%$ (13/84), the highest score was recorded in Adama, 42.86\% (6/14), and no positive case was detected in Bote and Bishoftu ( $\mathrm{p}<0.05)$ while intermediate scores were obtained from Batu, Arsi-negelle and Shashemene.

Conclusions In general, the present study provides important information on the epidemiology of NDV based on M-gene assay in Central Rift Valley of Oromia, Ethiopia, and highlights the importance of implementing surveillances and biosecurity practices in live poultry markets and village chickens.

\section{Background}

Newcastle Disease (ND) is an acute, mild to severe, highly infectious and pathogenic disease of domestic poultry, caged and aviary birds as well as wild birds caused by specified viruses of the Avian Paramyxovirus Type 1 (APMV-1) [1, 2]. Newcastle Disease Virus (NDV) is an enveloped, non-segmented, single-stranded negative-sense RNA virus with a helical morphology whose genome has six open reading frames (ORF) which encode for the following proteins: nucleoprotein (NP), phosphoprotein (P), matrix protein $(M)$, fusion protein $(F)$, hemagglutinin-neuraminidase $(H N)$ and RNA-dependent RNA polymerase (L). ND is caused by Newcastle disease virus (NDV) which is a highly infectious agent capable of causing high mortality in non-vaccinated chickens. The sub clinical forms of ND in vaccinated and/or NDV exposure flocks have synergistic effect with other bacterial or viral infections $[3,4]$.

In Ethiopia, like other African countries, ND causes devastating losses to the poultry industry [5]. In backyard poultry, the disease is endemic but recurs as frequent epidemic outbreaks with high mortality 
and thus affects the livelihoods of poor rural households who depend on poultry for food and income [6]. Backyard poultry management favors the existence and spread of diverse NDV strains by allowing free interaction of different poultry species and wild birds as well as the frequent introduction of birds from markets [7]. In many countries, matrix gene and fusion gene based qRT-PCR assays are often used as standard methods for NDV screening and pathotyping directly from clinical samples [8]. The qRT-PCR assay is not only faster and less cumbersome than the conventional diagnostic techniques, but also provides equal or even greater sensitivity of virus detection than the gold standard virus isolation method [9]. The choice of matrix gene detection in NDV screening is due its highly conserved nature in the NDV genome where matrix gene assay is able to detect most of NDV isolates [10]. Despite the wide spread problem of ND in Ethiopia in general and Oromia in particular [7, 11, 12], there is limited information about the genetic profile of NDVs circulating in backyard poultry in Ethiopia. Therefore, the aim of this study was to detect the existence of Newcastle Disease virus by molecular tool in non-vaccinated village poultry in central rift valley of Oromia, Ethiopia.

\section{Materials And Methods}

The study was conducted in selected Central Rift Valley areas of East Shoa (Bishoftu, Adama, Bote, Batu) and West Arsi Zone (Shashemene and ArsiNegelle) of Oromia Regional State (Fig. 1). East Shoa Zone extends between $70^{\prime} 33^{\prime} 50^{\prime \prime} \mathrm{N}-90^{\prime} 08^{\prime} 56^{\prime \prime} \mathrm{N}$ and from 380'24'10" $\mathrm{E}-400^{\prime} 05^{\prime} 34^{\prime \prime} \mathrm{E}$. The temperature of the area ranges from $10^{\circ} \mathrm{C}$ in uplands to over $30^{\circ} \mathrm{C}$ in rift valley depressions with the mean temperature of $20^{\circ} \mathrm{C}$. Since the large portion of the zone is located along the rift valley system, rainfall varies from $600 \mathrm{~mm}$ to $1000 \mathrm{~mm}$ with mean annual rainfall of $816 \mathrm{~mm}$. The livestock population of East Shoa zone is estimated to be 1,090,091 cattle, 319,598 sheep, 568,761 goats, 10644 horse, 7039 mules, 284, 583 donkey, 6818 camels, 14627 beehives and 1,250, 059 poultry. Out of a total 1,250,059 poultry, around $94 \%(1,169,710)$ are indigenous or village poultry whereas only $6 \%(69,562)$ are hybrids [13]. The livestock population of West Arsi Zone is estimated to be 1, 957, 066 cattle, 946, 595 sheep, 404, 118 goats, 214, 744 horses, 6, 304 mules, 210, 339 donkeys, 555 camels and 1, 105, 688 chicken [14].

\section{Study Populations}

The study populations were non-vaccinated village chickens from East Shoa and West Arsi Zones in Central Rift Valley of Oromia regional State, Ethiopia.

\section{Study Animals}

Study animals were non-vaccinated village chickens from randomly selected districts in East Shoa and West Arsi zones. Village chickens were sampled in respective of districts, sex and age. The age was determined based on history from the owners as young 3-6 months, adult 7-16 months and older more than 16 months [15].

\section{Study Design}


A cross-sectional study was conducted in non-vaccinated village chickens found in the study areas for the detection of Newcastle Disease during the period of January to May, 2019.

\section{Sample Size Determination}

Sample size was calculated based on the prevalence of $38.4 \%$, as previously reported by [11], using $95 \%$ confidence level and $5 \%$ marginal error. A formula according to [16] was used to determine the required sample size as indicated below:

$$
\mathrm{n}=\frac{z^{2} \operatorname{Pexp}(1-\operatorname{Pexp})}{d^{2}}
$$

Where; $\mathrm{n}$ = Sample size, $\mathrm{Z}$ = Statistic for a level of confidence, $\mathrm{d}^{2}=$ Required absolute precision, and $\mathrm{P}_{\exp }=$ Expected prevalence. Therefore, at $95 \%$ confidence level, the sample size was:

$$
\begin{aligned}
& n=\frac{1.96^{2} \text { Pexp }(1-\text { Pexp })}{d^{2}} \\
& n=\frac{3.8416 \times 0.384(0.616)}{(0.05)^{2}} \\
& n=\frac{0.909}{0.0025} \\
& n=364
\end{aligned}
$$

Hence, a total of 364 non-vaccinated village chickens were required to be sampled. However, 420 domestic birds were randomly selected at poultry markets and villages in the study areas to increase the precision of the study. To calculate the prevalence the following formula was used:

$$
\text { Prevalence }=\frac{\text { Number of Positive sample }}{\text { Total number of Sample }} \times 100
$$

\section{Sampling and Method of Data Collection}

A total of 420 non-vaccinated and healthy live chickens were sampled using random sampling technique from poultry markets and villages by equal distribution in the study areas on consecutive market days. Tracheal and cloacal swab samples were collected from live chickens by inserting sterile cotton tipped swab into the trachea gently swabbed its wall and cloacal swab deeply into the vent and gently swabbing the wall of the vent. Both the tracheal and cloacal swab samples were placed in sterile separate cryovial ( $2 \mathrm{ml}$ volume) containing $500 \mu \mathrm{l}$ of freshly prepared viral transport media (VTM). During sampling, all the samples were labeled, placed in ice pack $\left(4^{\circ} \mathrm{C}\right)$ and transported to molecular laboratory of National Animal Health Diagnostic and Investigation Center (NAHDIC), Sebeta, Ethiopia and stored at $-80^{\circ} \mathrm{C}$ until processing. Sample collection and transportation were conducted according to the standard techniques recommended by OIE [17].

\section{RNA extraction}


Viral RNA extractions from tracheal and cloacal swabs were conducted using Qiagen®viral RNA Mini kit according to manufacturer's instruction (Qiagen, 2014) as follows: - Swab samples collected with viral transport medium were centrifuged briefly at $8000 \mathrm{rpm}$ for 1 minute in order to get cell free supernatant. Then, $140 \mu \mathrm{l}$ of the supernatant were lysed by adding $560 \mu \mathrm{l}$ of buffer AVL containing carrier RNA. After ten minutes' incubation at room temperature, the sample was mixed and $560 \mu$ of $96 \%$ ethanol was added to filtrate and again mixed thoroughly. Samples containing $630 \mu \mathrm{l}$ of lysis buffer and absolute alcohol were transferred for binding to mini spin column and centrifuged at $8000 \mathrm{rpm}$ for 1 minute and old collection tube was replaced by a new collection tube. A $500 \mu \mathrm{l}$ wash buffer (AW1) was added and centrifuged at $8000 \mathrm{rpm}$ for 1 minute and a new collection tube was used. Again, a $500 \mu \mathrm{l}$ wash buffer (AW2) was added and centrifuged at full speed of 14,000 rpm for 3 minutes in order to remove any unwanted protein and others. Again, new collection tube was used and centrifuged at full speed of $14,000 \mathrm{rpm}$ for 1 minute without adding anything. A new and sterile $1.5 \mu \mathrm{l}$ of micro centrifuge tube was used followed by adding $60 \mu$ l of elution buffer (AVE) to mini spin column and incubated for 3 minutes at room temperature. Finally, the eluted RNA was kept at $-80{ }^{\circ} \mathrm{C}$ for storage.

\section{Real - Time Quantitative Polymerase chain reaction (qRT-PCR)}

One step qRT-PCR for conserved region of M-gene assay was performed using an Applied Biosystems 7500 fast thermocycler using the Forward Primer M + 4100- 5'-AGT GAT GTG CTC GGA CCT TC-3', Reverse Primer M-4220- 5'CCT GAG GAG AGG CAT TTG CTA-3'. Probe M + 4100- 5'FAM- TTC TCT AGC AGT GGG ACA GCC -TAMRA - 3' were used to specifically detect pathogenic strains of NDV (IDT). For Mgene assay, the following amounts of reagents per $25 \mu$ reaction were used: $5 \mu$ of kit supplied PCR buffer $(5 \mathrm{x}), 0.5 \mu \mathrm{l}$ of each primer $(10 \mathrm{pmol}), 1 \mu \mathrm{l}$ of probe $(6 \mathrm{pmol}), 0.8 \mu \mathrm{l}$ of kit supplied deoxynucleoside triphosphates (dNTPs), $1.25 \mu \mathrm{l}$ of $25 \mathrm{mM} \mathrm{MgCl}_{2}$ and $0.5 \mu \mathrm{l}$ of $13.3 \mathrm{u} / \mu \mathrm{l}$ of RNase inhibitor and $1 \mu \mathrm{l}$ Qiagen enzyme mix and 6.45 Rnase free water (QIAGEN). All the reagents in a single reaction tube (master mix) were mixed to ensure a homogenous distribution of the reagents. Aliquots of $17 \mu \mathrm{l}$ of prepared reagents were distributed in to applied biosystem plate depending on number of samples to be tested. Finally, $8 \mu$ of extracted RNA were added to each plate to get total volume of $25 \mu \mathrm{l}$ reaction. For controls, NDV known positive field isolates and RNase free water as positive and negative controls, respectively, were used. The plates were sealed with a sealer in order to avoid evaporation and placed in to the thermal cycler or rRT-PCR machine that was connected to computer with its own software (Applied biosystems sequence detection software version 1.4.0) and the program was adjusted for each specific reaction or set accordingly. The reverse transcription (RNA to cDNA) step was done for $30 \mathrm{~min}$ at $50^{\circ} \mathrm{C}$, followed by $15 \mathrm{~min}$ at $95^{\circ} \mathrm{C}$ incubation. The cycling conditions for the M-gene assay were programmed at 40 cycles of 10 second denaturation at $94{ }^{\circ} \mathrm{C}, 30$ second annealing at $52^{\circ} \mathrm{C}$, and extension at $72{ }^{\circ} \mathrm{C}$ for 25 second (Wise et al., 2004). The reporter dye (FAM) and quencher dye (TAMRA) signals were measured at the extension step of each cycle, and the threshold cycle (Ct.) for each sample was calculated. The samples that have a Ct. value $<35$ were considered as positive and $>35 \mathrm{Ct}$. value considered as negative for $\mathrm{M}$ genes based on qRT-PCR [18].

\section{Real-time reverse transcriptase polymerase chain reaction (rRT-PCR),}


rRT-PCR was performed using primer sequences with forward primer NOH-5'-TAC ACC TCA TCC CAG ACA GG-3' and reverse primer NOH- 5'-AGT CGG AGG ATG TTG GCA GC-3' (Europhins MWG operon) used to specifically detect pathogenic strains of NDV. The following amounts of reagents per $25 \mu$ reaction were used: $5 \mu$ l of kit supplied PCR buffer ( $5 x), 0.25 \mu$ l of each primer $(20 \mu \mathrm{M}), 0.5 \mu$ l of kit supplied deoxynucleoside triphosphates (dNTPs) of $10 \mathrm{Mm}, 0.1 \mu \mathrm{l}$ of $40 \mathrm{U} / \mu \mathrm{l}$ of RNase inhibitor, $0.5 \mu \mathrm{l}$ of one step RT-PCR enzyme mix and 13.4 $\mu$ l Rnase free water (QIAGEN). All the reagents in a single reaction tube (master mix) were mixed and in to $20 \mu \mathrm{l}$ of the mixed samples $5 \mu$ of extracted RNA or template were added to get a total volume of $25 \mu$ to each respective tube and were capped tightly in order to avoid evaporation and the tube were labeled. For controls, NDV known positive field isolates and RNase free water as positive and negative controls, respectively were used. After placing tubes, the thermal cycler or PCR machine was programmed for reverse transcription (RNA to CDNA) step and incubated for 30 min at $50^{\circ} \mathrm{C}$, followed by $15 \mathrm{~min}$ at $94^{\circ} \mathrm{C}$. The cycling conditions consisted 35 cycles and each cycle were having 30 second for denaturation at $94^{\circ} \mathrm{C}, 1 \mathrm{~min}$ for annealing at $55^{\circ} \mathrm{C}$, and extension at $68{ }^{\circ} \mathrm{C}$ for $1 \mathrm{~min}$ and additionally one cycle at $68^{\circ} \mathrm{C}$ for 7 min final extension [18].

\section{Gel electrophoresis}

A $2 \mu \mathrm{l}$ of loading dye and $8 \mu \mathrm{l}$ of amplified PCR products were mixed up and loaded in to separate lane (wells on the gel) and the gel was run for 45-60 minutes. The gel was placed under UV transilluminator or Gel doc machine that was connected to the computer with its respective software (Image Lab software version 5.0) for imaging. Finally, the presence or absence of band were observed and the image was captured.

\section{Results}

\section{Quantitative real-time PCR (qRT-PCR) based molecular detection of NDV in village chickens}

The current findings in village chickens for pooled five swab samples obtained in the study area for $\mathrm{M}$ gene qRT-PCR test with their $\mathrm{Ct}$. values are presented in Table 1. Out of the 84 pooled five samples tested by qRT-PCR for M gene, 14 (16.7\%) samples were detected for NDV where 13 (15.5\%) were identified as positive for NDV and 1 is having a Ct. value of 36.38 considered as negative for NDV in non-vaccinated village chickens.

Table 1: M gene qRT-PCR test Ct. values for NDV detection in non-vaccinated village chickens in Central Rift Valley of Oromia, Ethiopia. 


\begin{tabular}{|c|c|c|c|}
\hline Sample ID & Study areas & Swab type & Ct. value \\
\hline A1 & Adama & Cloaca & 24.82 \\
\hline A2 & Adama & Cloaca & 26.42 \\
\hline A3 & Adama & Trachea & 30.82 \\
\hline A4 & Adama & Trachea & 33.87 \\
\hline A5 & Adama & Trachea & 27.20 \\
\hline A6 & Adama & Trachea & 31.23 \\
\hline A7 & Adama & Trachea & 36.38 \\
\hline AN1 & Arsi Negelle & Cloaca & 23.41 \\
\hline AN2 & Arsi Negelle & Cloaca & 34.85 \\
\hline AN3 & Arsi Negelle & Trachea & 28.78 \\
\hline BA1 & Batu & Trachea & 31.50 \\
\hline $\mathrm{S} 1$ & Shashemene & Trachea & 28.96 \\
\hline S2 & Shashemene & Trachea & 24.39 \\
\hline S3 & Shashemene & Trachea & 23.68 \\
\hline \multicolumn{2}{|c|}{ Mean } & & 28.41 \\
\hline
\end{tabular}

The present findings of both positive and negative controls (Figure 2) in non-vaccinated village chickens swab samples pooled five based on qRT-PCR test for M gene of NDV was indicated (Figure 3) when read from Applied Biosystems 7500 fast real time PCR thermo cycler.

\section{Prevalence of ND in village chickens using qRT-PCR for M gene test by Age and Sex}

The prevalence of ND based on M gene assay was higher in male (16.10\%) than female $(14.67 \%)$ chicken even though there was statistically no significance difference $(p>0.05)$ by sex (Table 2$)$. On the other hand, the prevalence of ND was higher in Adult (16.59\%) but lower in old chicken (11.11\%) as shown in Table 2.

Table 2: Prevalence of Newcastle disease in village chickens by Sex and Age in the study area. 


\begin{tabular}{|c|c|c|c|c|}
\hline Risk factors & Number examined & Number positive & Prevalence \% & p-value \\
\hline \multicolumn{5}{|l|}{ Sex } \\
\hline Male & 236 & 38 & 16.1 & $>0.05$ \\
\hline Female & 184 & 27 & 14.67 & \\
\hline \multicolumn{5}{|l|}{ Age } \\
\hline Young & 146 & 23 & 15.75 & $<0.05$ \\
\hline Adult & 211 & 35 & 16.59 & \\
\hline Old & 63 & 7 & 11.11 & \\
\hline
\end{tabular}

\section{Prevalence of ND using qRT-PCR for M gene test in village chickens in the study districts}

The overall ND prevalence was $15.48 \%(13 / 84)$ in the study districts where the highest score was from Adama (42.86\%) while none was detected in Bote and Bishoftu (Table 3). There was statistically no significance difference $(p>0.05)$ among the study districts.

Table 3: Prevalence of Newcastle disease in village chickens in the study Districts.

\begin{tabular}{rcccc}
\hline \multicolumn{1}{l}{ Districts } & No. examined in pool of five & No. Positive & Prevalence \% & p-value \\
\hline East Shoa Zone & 14 & & & \\
\hline Adama & 14 & 6 & 42.86 & \\
Batu & 14 & 1 & 7.14 & $<0.05$ \\
Bishoftu & 14 & 0 & 0 & \\
Bote & 0 & 0 & \\
West Arsi Zone & 14 & 3 & 21.43 & $>0.05$ \\
Arsi Negelle & 14 & 3 & 21.43 & \\
Shashemene & 84 & 13 & 15.48 & \\
\hline Total & & 3 & & \\
\hline
\end{tabular}

The current qRT-PCR test results also revealed a higher detection rate for M-gene from tracheal swab samples (TS), $21.43 \%$ (9/42), as compared to cloacal swab samples (CS), 9.52\% (4/42), collected from village chicken from the study areas (Table 4).

Table 4: qRT-PCR test result for M-gene detection rate from swab samples from study area. 


\begin{tabular}{ccccc}
\hline Swab type & No examined & No positive & Detection rate \% & p-value \\
\hline Trachea swab & 42 & 9 & 21.43 & $>0.05$ \\
Cloacal swab & 42 & 4 & 9.52 & \\
\hline Total & 84 & 13 & 15.47 & \\
\hline
\end{tabular}

\section{rRT-PCR- based molecular detection of NDV}

Ten samples were tested by rRT-PCR assay for the detection of M-gene. Each band represents the extracted RNA from ten samples (Figure 4). Detection of $\mathrm{M}$ gene in the present study by rRT-PCR (Figure 4 ) is a demonstration of infection by the virus in these chickens.

\section{Test agreement result between qRT-PCR and rRT- PCR detection technique}

The kappa test agreement between qRT-PCR and rRT- PCR were having a value of 0.615 which indicates substantial result agreement between the two raters (Table 5).

Table 5: Kappa test agreement between qRT-PCR and rRT- PCR of Newcastle disease in the study area.

\begin{tabular}{|c|c|c|c|c|c|}
\hline & & & \multicolumn{2}{|c|}{ rRT-PCR } & \multirow[b]{2}{*}{ Total } \\
\hline & & & Negative & Positive & \\
\hline \multirow[t]{6}{*}{ qRT-PCR } & Negative & Count & 1 & 0 & 1 \\
\hline & & \% within qRT-PCR & $100.0 \%$ & $0.0 \%$ & $100.0 \%$ \\
\hline & & $\%$ within qRT-PCR & $50.0 \%$ & $0.0 \%$ & $10.0 \%$ \\
\hline & Positive & Count & 1 & 8 & 9 \\
\hline & & $\%$ within qRT-PCR & $11.1 \%$ & $88.9 \%$ & $100.0 \%$ \\
\hline & & \% within rRT-PCR & $50.0 \%$ & $100.0 \%$ & $90.0 \%$ \\
\hline \multirow[t]{3}{*}{ Total } & & Count & 2 & 8 & 10 \\
\hline & & $\%$ within qRT-PCR & $20.0 \%$ & $80.0 \%$ & $100.0 \%$ \\
\hline & $\%$ within rRT-PCR & $100.0 \%$ & $100.0 \%$ & $100.0 \%$ & \\
\hline
\end{tabular}

\begin{tabular}{|c|c|c|c|c|}
\hline \multicolumn{5}{|c|}{ Symmetric Measures } \\
\hline & Value & Asymptotic Standard Error ${ }^{\mathrm{a}}$ & Approximate $\mathrm{T}^{\mathrm{b}}$ & Approximate Significance \\
\hline Measure of Agreement Kappa & .615 & .337 & 2.108 & .035 \\
\hline $\mathrm{N}$ of Valid Cases & 10 & & & \\
\hline
\end{tabular}

\section{Discussion}

The present study on ND from non-vaccinated village chicken using qRT-PCR for M gene assay revealed an overall prevalence of $15.48 \%$ in the study area ranging from $0 \%$ at Bishoftu and Bote to $42.86 \%$ at 
Adama. The Detection of NDV at $15.48 \%$ obtained in this study (Table 3 ) supports the view that ND is endemic in Central Rift Valley of Oromia. Detection of $\mathrm{M}$ gene in the present study by RT-PCR (Fig. 4) is a demonstration of infection by the virus in these chickens. The occurrence of positive result supports the use of the technique to identify NDV. Positive samples obtained in this study can further be subjected to pathotyping and phylogenetic studies which is an advantage that goes beyond the previous serological study. Even though, the distribution of the disease differs among the study areas in Eastern Shoa Zone using qRT-PCR analysis with statistically significance difference $(p<0.05)$, [12] reported an overall prevalence of $26.7 \%$ by using rRT-PCR for fussion (F) gene assay from Adama and Bishoftu which is in a close resemblance with our current findings $(21.42 \%)$ when it was analyzed only for Adama and Bishofitu. In addition, using a rRT-PCR for M gene study conducted by [11] in three selected districts (Batu, Bishoftu and TikurWuha) in rift valley areas revealed an overall prevalence of $8.4 \%$ which is less than the current finding and this could be due to the small area coverage. Even though the negative results from the qRT-PCR test in Bishoftu and Bote seem strange, a molecular and serological study conducted for NDV from Iran in non-vaccinated village chicken also showed negative result on qRT-PCR for $M$ gene assay but positive reaction on $\mathrm{HI}$ test [19]. They concluded that the serological finding may imply a circulation of NDV antibody on the native chickens in the area but by molecular test no virus was detected since there was no occurrence of active viral infection.

The result of the present study (15.48\%) was higher than the findings of other researches done by serological detection method in Eastern Shoa and Kersana Kondaltity district with an overall seroprevalence of $5.9 \%$ and $5.6 \%$, respectively $[7,20]$. In another serological study conducted in selected areas in rift valley an overall sero-prevalence of $5.6 \%$ was reported [15] and $11.6 \%$ [11] from which one can discern out that the results under the present study, molecular tool, outweighs the results of the former studies by serological (ELISA) method. The overall discrepancy of the findings might be due to variations on management system that may serve as a stress factor that favor infection or the diagnostic tools used.

The present higher proportion (42.86\%) of qRT-PCR positive result for NDV in chickens from Adama district might indicate chickens have been previously infected by the non-virulent strains or survived outbreaks of the virulent NDV strains [21]. Moreover, the detected high prevalence of ND in this study may mean that natural infection could have occurred since all the chickens were non-vaccinated. However, clinical signs of ND were not observed on the examined chickens during sample collection. Furthermore, the higher prevalence recorded in Adama district cannot be attributed to more chicken had been sampled (70 chicken sampled) compared to other study districts (70 chicken sampled), because as the number of sample size increase the probability of having higher prevalence's also increase. The present study also revealed significant variation with almost closer agro-ecology between East Shoa and West Arsi Zones.

The findings in village chickens of the present study also found out to be higher than the results reported from North Eastern Coast and Amazon Biome of Brazil from 1022 cloacal/tracheal samples collected from domestic and wild birds tested by qRT-PCR targeting the M gene segment of APMV-1, $7(0.7 \%)$ were 
positive [22]. These variations could have been attributed to seasonal differences during sampling periods, geographical location and type of birds employed for the studies.

In the present study a higher detection rate by qRT-PCR for M gene assay was obtained from pooled tracheal $21.43 \%(9 / 42)$ than cloacal $9.52 \%$ (4/42) swab samples with statistically insignificance difference $(p>0.05)$. This is in agreement with the finding of [7] who reported higher positivity of tracheal than cloacal pooled swab samples by rRT-PCR for F gene assay speculating the presence of viscerotropic velogenic virulent NDV in the study areas. On the other hand, Haque and his colleagues detected NDV from pooled oropharyngeal and cloacal swabs and suggested that the chickens are in the early or advanced stage of the disease since NDV is transmitted through aerosol and ingestion or the chickens are on the shedding stage of the infection [23].

The difference in the prevalence between adult, young and old age was statistically significant $(p<0.05)$, which agrees with the finding of [24] who stated that the young had a significantly lower ND prevalence than the adult. Furthermore, the result of the current study corroborates with the findings of [25] from Alamata District, Southern Tigray, Ethiopia with sero-prevalence of $17.3 \%$ and $29.7 \%$ for young and adult, respectively. They hypothesized that, more frequent exposure of Adult birds to field virus, which might have survived the disease at an earlier age.

The present study revealed a higher prevalence rate of ND among the male $16.1 \%(38 / 236)$ compared to female chickens $14.67 \%(27 / 184)$ with statistically insignificance difference $(p>0.05)$. This finding corroborates with the study reported by [26] in the Southern and Rift Valley districts of Ethiopia where a higher sero-prevalence rate among males $(21.74 \%)$ than females $(19.16 \%)$ was observed. In contrary to this finding, [27] reported a slightly higher sero-prevalence among female $(32.63 \%)$ chickens when compared with male $(31.63 \%)$ chickens in Ethiopia. The higher prevalence of the disease observed in the present study could be due to higher number of male chickens involved by chance in the study area during sampling than females.

\section{Conclusion}

The present study provides important information on the epidemiology of NDV based on M-gene assay in Central Rift Valley of Oromia, Ethiopia, and highlights the importance of implementing molecular surveillances and biosecurity practices in live poultry markets and village chickens. Because the current study revealed the presence of NDV among village chickens that represents a continual threat to newly hatched susceptible chicks and to commercial poultry, we recommend the immediate vaccination of village chickens in order to raise the immune status of village chickens to prevent the likelihood of ND outbreaks in Central Rift Valley of Oromia. In addition we recommend a detail molecular characterization study of the virus in Central Rift Valley of Oromia and in Ethiopia in its larger context to better understand the molecular epidemiology of the disease and to characterize the virus strains that circulates in the country that plays a great role in designing appropriate control strategy of ND. 


\section{Abbreviations}

APMV

cDNA

CSA

Ct

ELISA

F

$\mathrm{HI}$

$\mathrm{HN}$

IDT

L

M

NAHDIC

ND

NDV

NP

OIE

ORF

P

PCR

qRT-PCR

rRT-PCR

VTM
Avian Paramyxovirus

Complementary Deoxyribonucleic acid

Central Statistical Agency

Cycle Threshold

Enzyme Linked Immuno Sorbent Assay

Fusion Protein

Hemagglutination Inhibition

Hemagglutinin Neuraminidase

Integrated DNA Technologies

Large RNA Polymerase

Matrix Protein

National Animal Health Diagnosis and Investigation Center

Newcastle Disease

Newcastle Disease Virus

Nucleoprotein

Office International des Epizooties

Open Reading Frames

Phospho-protein

Polymerase Chain Reaction

Real -Time Quantitative Polymerase chain reaction

Real Time Reverse-transcriptase Polymerase Chain Reaction

Virus Transport Media

\section{Declarations}




\section{Ethics Approval}

Ethics approval was obtained from Adama Science and Technology University Ethical Review Committee

\section{Consent for publication}

Not applicable

\section{Availability of data and materials}

The datasets used and/or analyzed during the current study are available from the corresponding author on request.

\section{Competing interests}

The authors declare that there is no conflict of interest.

\section{Funding}

Small amount of financial support was obtained from Adama Science and Technology University.

\section{Authors' contributions}

AM and HD participated in the design of the study, sample collection, performed M-gene assay, data analysis, and drafted the manuscript. RB and AA participated in the optimizing laboratory works. All authors read and approved the final manuscript.

\section{Acknowledgments}

We would like to acknowledge both Adama Science and Technology University and National Animal Health Diagnostic and Investigation Center (NAHDIC) for the overall technical and logistic support they provided us during the research work. The authors also would like to acknowledge poultry owners for their cooperation during sample collection.

\section{References}

1. Alexander D: Newcastle disease, other avian paramyxoviruses, and pneumovirus infections. In: Saif, Y. M., Barnes, H. J., Glisson, J. R., Fadly, A. M., McDougald, L. R. and Swayne, D. E. ed., Diseases of Poultry 11th (ed.). lowa State University Pres; 2003: 63-99.

2. Amarasinghe GK, Bao Y, Basler CF, Bavari S, Beer M and Bejerman N: Taxonomy of the order Mononegavirales. Arch Virol 2017, 162: 2493-2504.

3. Capua I and Alexander DJ: Human health implications of avian influenza viruses and paramyxoviruses. Eur J Clin Microbiol Infect Dis 2004, 23: 1-6. 
4. Perozo F, Marcano R and Afonso CL: Biological and phylogenetic characterization of a genotype VII Newcastle disease virus from Venezuela: efficacy of field vaccination. J of cli microbio/ 2012, 50(4), 204-208.

5. ACIAR, "Newcastle disease control in Africa," May 2018, http://aciar.gov.au/files/ias_87-web.pdf.

6. Copland JW and Alders RG: The Australian village poultry development programme in Asia and Africa. World's Poul Sci J 2013. 61(1): 31-38.

7. Chaka H, Goutard F, Bisschop SP and Thompson PN: Sero-prevalence of Newcastle disease and other infectious diseases in backyard chickens at markets in Eastern Shewa zone, Ethiopia. Poult Sci 2012, 91: 862-869.

8. Miller PJ, Decanini EL and Afonso CL: Newcastle disease: evolution of genotypes and the related diagnostic challenges. Infect Gen and Evol 2010, 10(1):26-35.

9. Bello BM, Yusoff K, Ideris A, Hair-Bejo M, Peeters PH and Omar RA: Diagnostic and Vaccination Approaches for Newcastle Disease Virus in Poultry: The Current and Emerging Perspectives. BioMed Res Int 2018, DOI: 10.1155/2018/7278459.

10. Kim LM, King DJ, Curry P E, et al: Phylogenetic diversity among low-virulence newcastle disease viruses from waterfowl and shorebirds and comparison of genotype distributions to those of poultryorigin isolates. J Viro 2007, 81(22): 12641-12653.

11. Terefe D, Belaineh R, Chaka H, Sombo M, Mekuria A, Gugsa G, Lelisa K and Damena D: Serological and Molecular Study of Newcastle Disease Virus in Village Chickens in Selected Rift-Valley Areas, Ethiopia. J Vet Sci Technol 2015, 6(6): 1-4.

12. Miressa $Y$, Cherinet $Y, B$ srat $A$ and Tadesse F: Investigation of Newcastle Disease Virus Using Reverse Transcription Polymerase Chain Reaction in Selected Districts of Eastern Shewa, Ethiopia. J Vet Sci Technol 2016, 7: 380-384.

13. CSA (2013). Report on livestock and livestock characteristics (private peasant holdings). Addis Ababa: Central Statistical Agency.

14. CSA, (2014). Central Statistical Agency of the Federal Democratic Republic of Ethiopia. Agricultural SampleSurvey of 2014/2015 (2007 E.C). Volume II. Report on Livestock and Livestock Characteristics (Private Peasant Holdings), Central Statistical Agency, Addis Ababa, Ethiopia.

15. Belayneh G, Moses N, Melese B and Fufa D: Seroprevalence of Newcastle Disease Virus Antibodies in Village Chickens in Kersana-kondalaity District, Ethiopia. Global Vet 2014, 12 (3): 426-430.

16. Thrusfield M: Veterinary Epidemiology, 3rd edn, Blackwell Science, Oxford, UK. Pp; 2005: 149, 231.

17. OIE (2008). Newcastle disease. In: OIE terrestrial manual: manual of diagnostic tests and vaccines for terrestrial animals. World Organisation for Animal Health. Paris. France.

18. OIE (2013). Newcastle disease. Manual of Diagnostic Tests and Vaccines for Terrestrial Animals: Mammals, Birds and Bees Paris, france, chapter 2.3.14.

19. Rezaeianzadeh G, Dadras H, Safar A, Ali M and Nazemshirazi MH: Serological and molecular study of Newcastle disease virus circulating in village chickens of Fars province, Iran. J Vet Med Anim 
Health 2011, 3 (8): 105-111.

20. Regasa C, Fufa D, Berihanu S and Hunduma D: Sero-prevalence of Newcastle disease in backyard chickens in mid rift valley of Oromia, Ethiopia. Work Poster. Association Institution. Montpellier, France. Trop Vet Med 2007, 1: 121-124.

21. Abdullsattar F: Newcastle disease. Vet Med J 2004, 1: 157-165.

22. Thomazelli LM, Araujo J, de Ferreira C, Hurtado R, Oliveira DB, Ometto T, Golono M, Sanfilippo L, Demetrio C, Figueiredo ML and Durigon EL: Molecular Surveillance of the Newcastle Disease Virus in Domestic and Wild Birds on the North Eastern Coast and Amazon Biome of Brazil. $J$ of Poul Sci 2012, 14(1): 1-7.

23. Haque MH, Hossain MT, Islam MT, Zinnah MA, Khan MS, Islam MA: Isolation and detection of Newcastle disease virus from field outbreaks in broiler and layer chickens by reverse transcriptionPolymerase chain reaction. J Vet Med 2010, 8(2): 87-92.

24. Vui TQ, Lohr JE, Kyule MN, Zessin KH and Baumann MP: Antibody levels against Newcastle disease virus, infectious bursal disease virus, and avian influenza virus in rural chickens in Vietnam. Int $J$ Poul Sci 2002, 1: 127-132.

25. Getachew B, Moses N, Kyule, Melese B and Fufa D: Sero-prevalence of Newcastle Disease Virus Antibodies in Village Chickens in Kersana kondalatiy District, Ethiopia. Glob Vet 2014, 12: 426-430.

26. Zeleke A, Sori T, Gelaye E and Ayelet G: Newcastle disease in village chickens in the southern and rift valley districts in Ethiopia. Int J Poult Sci 2005, 7: 507-510.

27. Tadesse S, Ashenafi $\mathrm{H}$ and Zeleke A: Seroprevalence study of Newcastle disease in local chickens in central Ethiopia. Intl J App Res Vet Med 2005, 3(1): 25-29.

\section{Figures}




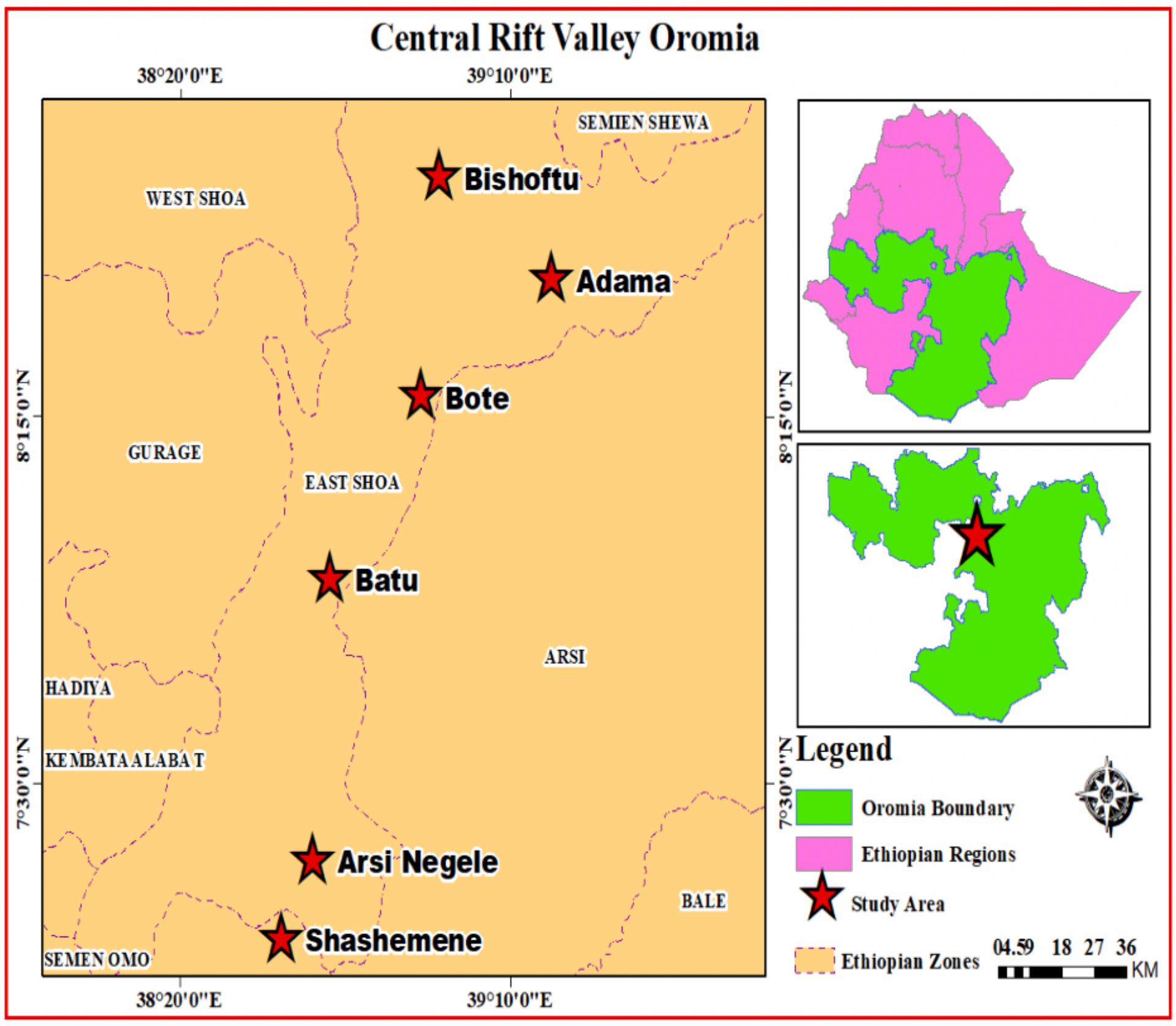

Figure 1

Map of study area, East Shoa and West Arsi Zones in Central Rift Valley of Oromia regional State, Ethiopia (by ArcGIS 10.4.1). 


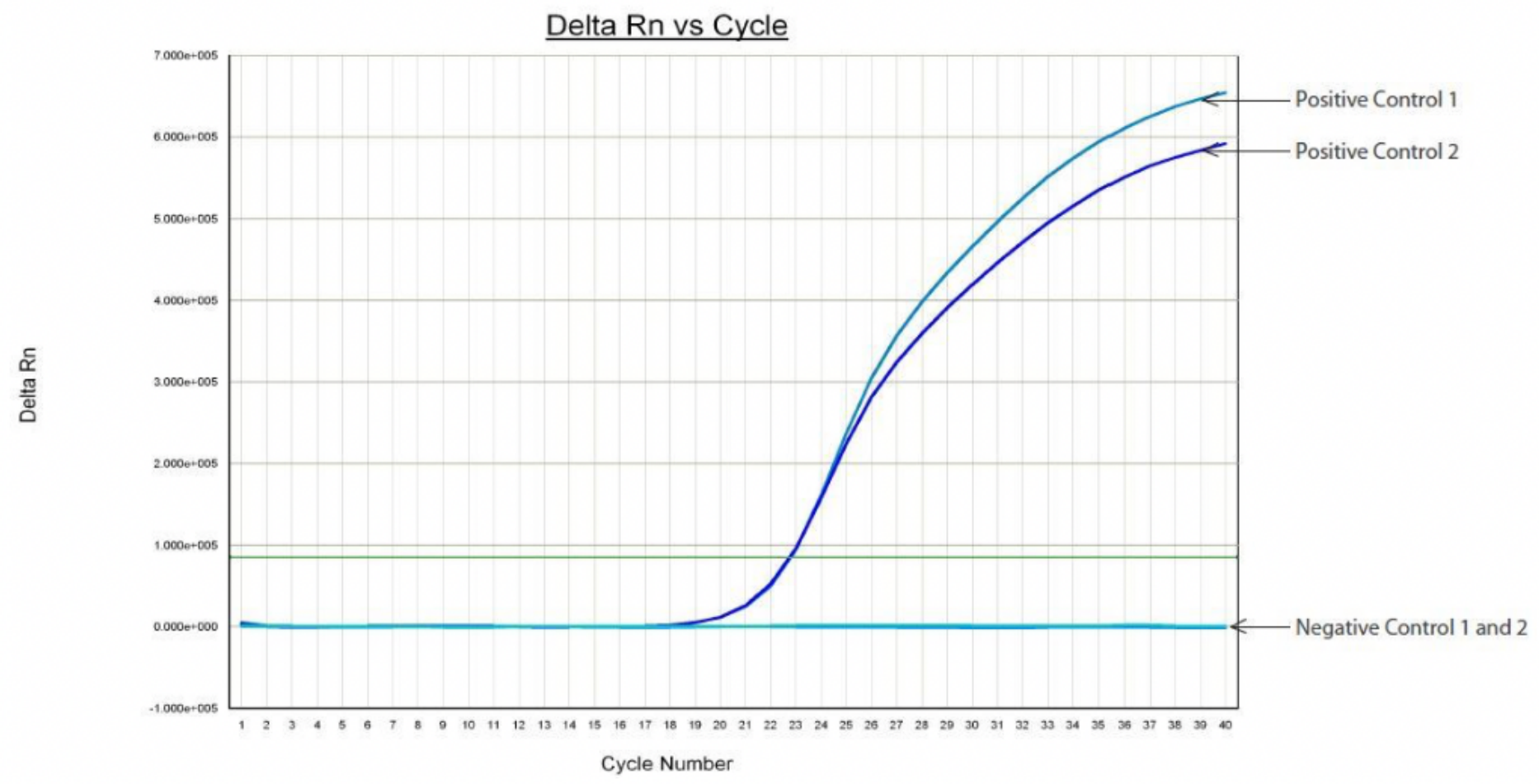

Figure 2

Positive and negative controls from qRT-PCR for $\mathrm{M}$ gene test. 
Delta Rn vs Cycle

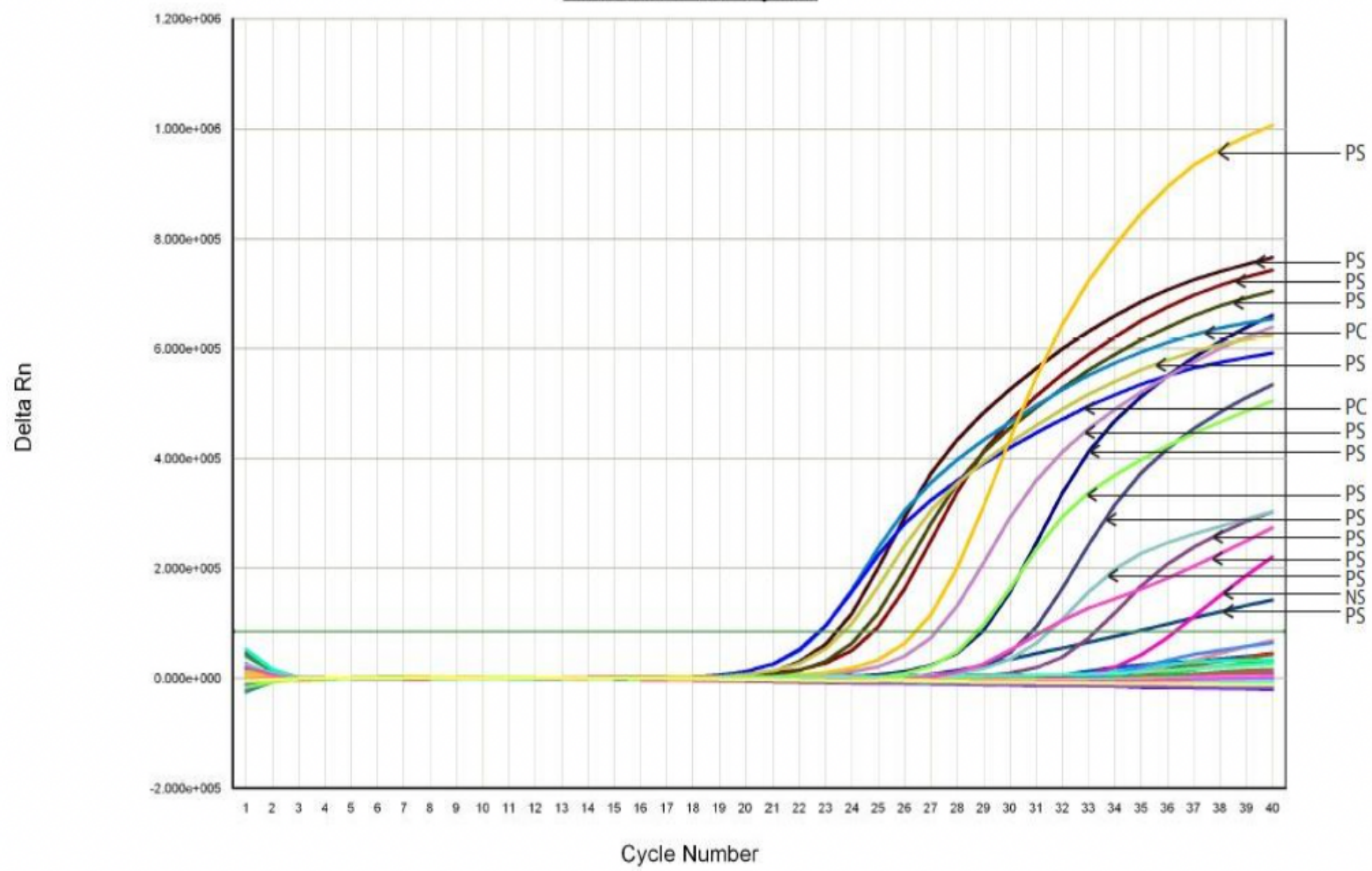

\section{Figure 3}

Amplification plot result of qRT-PCR test for $\mathrm{M}$ gene with their $\mathrm{Ct}$. value in village chickens where PS, PC, NS were positive sample, positive control and negative sample, respectively.

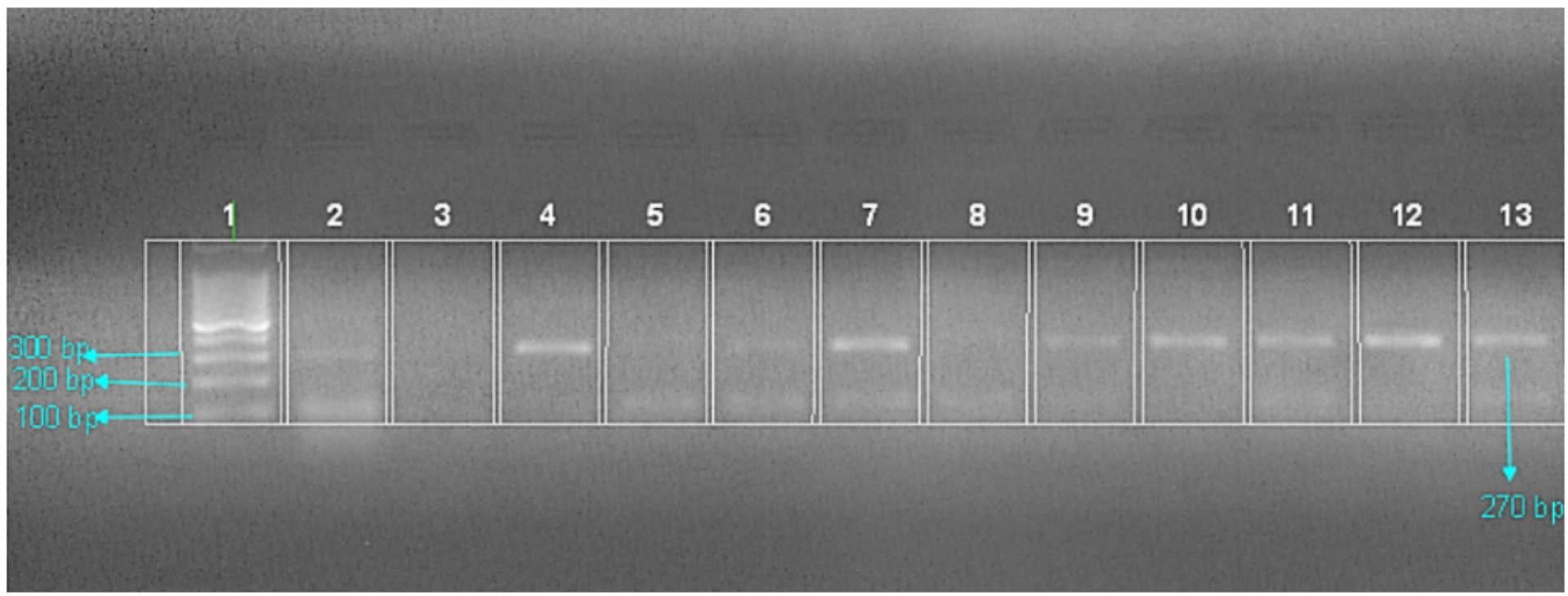

Figure 4 
Gel electrophoresis in $2 \%$ Agarose gel for rRT-PCR amplified product of Newcastle disease virus (270bp) specific products. Lanes 4, 6, 7, 9, 10, 11, 12, 13 indicates positive for NDV and lane 5, 8 negative bands for NDV. Lane 1 for marker or ladder of 100bp; while lane 2 and 3 as positive and negative controls, respectively. 